Research Journal of Biological Sciences 7 (1): 4-13, 2012

ISSN: $1815-8846$

(C) Medwell Journals, 2012

\title{
Zinc and Cadmium Resistance Mechanism of Pseudomonas aeruginosa PDMZnCd2003
}

\author{
${ }^{1} \mathrm{O}$. Meesungnoen, ${ }^{1} \mathrm{~W}$. Nakbanpote, ${ }^{1} \mathrm{R}$. Thiwthong and ${ }^{2} \mathrm{~K}$. Thumanu \\ ${ }^{1}$ Department of Biology, Faculty of Science, Mahasarakham University, Kamrieng, \\ Kantaravichai, 44150 Mahasarakham, Thailand \\ ${ }^{2}$ National Synchrotron Research Center, Suranaree, Muang, 30000 Nakhon Ratchasima, Thailand
}

\begin{abstract}
Pseudomonas aeruginosa PDMZnCd2003 is a Plant Growth Promoting Bacteria (PGPB) that was isolated from the rhizosphere of a $\mathrm{Zn} / \mathrm{Cd}$ hyperaccumulative plant. This research aims to study the effect of $\mathrm{Zn}$ and/or $\mathrm{Cd}$ on the growth of $P$. aeruginosa $\mathrm{PDMZnCd} 2003$ and $\mathrm{Zn}$ and $\mathrm{Cd}$ tolerance mechanisms. The results showed that $\mathrm{Zn}$ and $\mathrm{Cd}$ treatments affected the growth of $P$. aeruginosa PDMZnCd2003 in Nutrient Broth (NB). $\mathrm{Zn}$ and $\mathrm{Cd}$ also induced the bacterium to secret yellow-green chemicals. Scanning Electron Microscopy (SEM) indicated that the bacterium produced large amounts of Extracellular Polymeric Substance (EPS) under the heavy metals treatments, especially $\mathrm{Cd}$. The EPS were removed from native cells of $P$. aeruginosa PDMZnCd2003 by $\alpha$-glucoamylase to become EPS-free cells. Statistical analyses of FT-IR spectra separated the native cells into control group and group with native cells treated with $\mathrm{Zn}$ and/or Cd by the shifts in $\alpha$-helix and amide II. EPS-free cells were separated into three subgroups of control, EPS-free cells treated with Cd and EPS-free cells treated with $\mathrm{Zn}$ and $\mathrm{Zn}$ plus $\mathrm{Cd}$. The $\alpha$-helix and amide II peak shifts were found in the sub-groups of EPS-free cells treated with $\mathrm{Zn}$ and $\mathrm{Zn}$ plus $\mathrm{Cd}$ while the amount of $\alpha$-helix was highest in EPS-free cells treated with $\mathrm{Cd}$. In addition, there were shifts of sulfur groups and $\mathrm{C}-\mathrm{O}$ bonds in both native cells and EPS-free cells after $\mathrm{Zn}$ and/or Cd treatments. Therefore, the biochemical structures involving in $\mathrm{Zn}$ and $\mathrm{Cd}$ accumulation were carbonyl, amine groups, protein containing thiol (-SH) groups and $\mathrm{C}-\mathrm{O}$ bonds. Moreover, this study proposes $P$. aeruginosa $\mathrm{PDMZnCd} 2003$ has some specific mechanisms to tolerate $\mathrm{Cd}$ which are different from the mechanism responding to $\mathrm{Zn}$ and $\mathrm{Zn}$ plus $\mathrm{Cd}$.
\end{abstract}

Key words: Pseudomonas aeruginosa, FT-IR, zinc, cadmium, bacterium, $\alpha$-helix, Thailand

\section{INTRODUCTION}

Metal pollution problems occur when human activity either disrupts the normal biogeochemical cycles or concentrates metals; examples of such activities include mining and ore refinement (Kabata-Pendias and Pendias, 1992; Roane and Miller, 1994). Metal wastes can exist as individual metals or more often as metal mixtures. Baker et al. (1990) reported that Cadmium (Cd) never occurs in isolation in natural environments but rather, appears mostly as a guest metal in Zinc (Zn) mineralization. The soil in the fields of Phatat Phadaeng sub-district, Mae Sot, Tak province, Thailand is a source of $\mathrm{Zn}$ mineralization. The total $\mathrm{Cd}$ concentrations in the soil in Mae Sot are positively correlated with total $\mathrm{Zn}$ concentrations in the soil (Simmons et al., 2005, 2009). The health impacts of $\mathrm{Cd}$ overexposure on the Mae Sot population have been reported since, 2007 (Swaddiwudhipong et al., 2007, 2010; Teeyakasem et al.,
2007). Therefore, the problem of $\mathrm{Cd}$ and $\mathrm{Zn}$ contamination in the Mae Sot area needs to be remediated. Phytoremediation is a suitable method to remove heavy metals from contaminated soil. Phytoremediation takes advantage of a cost-effective, environmentally friendly, carbon neutral approach for the cleanup of toxic pollutants (Blaylock and Huang, 2000; Rascio and Navari-Izzo, 2011; Prasad et al., 2010). In addition, the association of plant and microorganism in the rhizosphere can enhance removal of the contaminants. Therefore, microbial augmentations of Plant Growth-promoting Bacteria (PGPB) have been investigated to improve phytoremediation (Jing et al., 2007; Zhuang et al., 2007). Plant Growth-promoting Bacteria (PGPB) have the ability to promote a plant's growth (increase biomass) and increase tolerance to toxic heavy metals by nitrogen fixation, phosphate solubilisation, sulfate oxidation and synthesis of phytohormones such as Indole-3-Acetic Acids (IAA), cytokinins, gibberellins and

Corresponding Author: W. Nakbanpote, Department of Biology, Faculty of Science, Mahasarakham University, Kamrieng, Kantaravichai, 44150 Mahasarakham, Thailand 
Aminocyclopropane-1 -Carboxylate (ACC) deaminase and Induce Systemic Resistance (ISR) mechanisms in the plant (Zhuang et al., 2007; Mukerji et al., 2006; Rajkumar et al., 2009). In the previous research, Plant Growth-Promoting Bacteria (PGPB) were isolated from $\mathrm{Zn} / \mathrm{Cd}$ contaminated soil near the rhizosphere of Gynura pseudochina (L.) DC., which is a $\mathrm{Zn} / \mathrm{Cd}$ hyperaccumulator growing in a zinc mine (Panitlertumpai et al., 2008; Phaenark et al., 2009). API20E biochemical test and genetic characterization indicated that the isolated PDMZnCd2003 was Pseudomonas aeruginosa. The bacterium was able to tolerate high $\mathrm{Zn}$ and $\mathrm{Cd}$ concentrations and had plant growth promoting properties of IAA production, nitrogen fixation and phosphate solubilisation (Nakbanpote et al., 2010). However, the $\mathrm{Zn}$ and $\mathrm{Cd}$ defense mechanism of $P$. aeruginosa $\mathrm{PDMZnCd} 2003$ should be researched before applying the bacterium for $\mathrm{Zn} / \mathrm{Cd}$ phytoremediation.

Therefore, this research aims to study the effect of $\mathrm{Zn}$ and/or $\mathrm{Cd}$ on the growth of $P$. aeruginosa PDMZnCd2003. The $\mathrm{Zn}$ and Cd tolerance mechanisms of the bacterium were studied by Fourier Transform-Infrared (FT-IR) microspectroscopy, using a non-destructive method to indicate the change of functional groups in the treated cells. In addition, Transmission Electron Microscopy (TEM) and Scanning Electron Microscopy connected with Energy Dispersive X-ray spectroscopy (SEM/EDS) were carried out to study the bacterial cells.

\section{MATERIALS AND METHODS}

The bacterial cells of $P$. aeruginosa PDMZnCd2003 were separated into native cells and EPS-free cells. The native cells were untreated bacterial cells. The EPS-free cells were cells treated with $\alpha$-glucoamylase (Fluka, USA) to remove the Extracellular Polymeric Substance (EPS) following the method of Ueshima et al. (2008). The native cells and EPS-free cells were cultivated in Nutrient Broth (NB) (Himedia, India) and NB supplemented with $\mathrm{Zn}$ (20 $\left.\mathrm{mg} \mathrm{L}^{-1}\right), \mathrm{Cd}\left(20 \mathrm{mg} \mathrm{L}^{-1}\right)$ and $\mathrm{Zn}$ plus $\mathrm{Cd}\left(20 \mathrm{mg} \mathrm{L}^{-1}\right.$ of $\mathrm{Zn}, \mathrm{Cd}$ ). The $\mathrm{Zn}$ and $\mathrm{Cd}$ were obtained from analytical grade $\mathrm{ZnSO}_{4} \cdot 7 \mathrm{H}_{2} \mathrm{O}$ (Ajax Finechem, Australia) and $\mathrm{CdSO}_{4} \cdot 8 \mathrm{H}_{2} \mathrm{O}$ (Ajax Finechem, Australia), respectively. The sample code is shown in Table 1. The concentrations of $\mathrm{Zn}$ and $\mathrm{Cd}$ in the NB media were analyzed by FlameAtomic Absorption Spectroscopy (FAAS) (Shimadzu AA-680, Japan) and the changing $\mathrm{pH}$ was detected with a $\mathrm{pH}$ meter (Denver Instrument, Model 215, USA). Bacterial growth curves were monitored by two methods: optical density at $660 \mathrm{~nm}$ by a Vis-spectrophotometer (ThermoFisher Scientific, Spectronic Genesys 20, USA) and total protein content by Bradford Protein Assay (Bradford, 1976). After cultivation, bacterial cells were collected by centrifugation and washed with $0.85 \%(\mathrm{w} / \mathrm{v})$ $\mathrm{NaCl}$ and deionized water. The bacterial cells were centrifuged and washed with deionized water before being freeze dried using a Lyophilizer (Freeze-Dry system-77530 Labconco, USA). The dried bacterial sample was put on double sided carbon tape (Ted Pella, Inc., USA) on aluminum straps and analyzed with a Scanning Electron Microscope connected to an Energy Dispersive X-ray Spectroscopy (SEM/EDS) (Jeol JSM-6460 LV, Japan). The glucoamylase treated cells were studied for optimal EPS removal time by Transmission Electron Microscopy (TEM) (Joel JSM 1230, Japan). The cell samples were prepared by dropping a cell suspension on a formvar coated grid and straining with $5 \%(\mathrm{w} / \mathrm{v})$ uranyl acetate. FT-IR microspectroscopy analysis was carried out by dropping a cell suspension on an IR reflected kevey slide and then vacuum drying for $24 \mathrm{~h}$. The sample slides were analyzed by IR spectrometer (Tensor 27, Bruker Optic) connected to an IR microscope (Hyperion 2000, Bruker Optic) and Mercury Cadmium Tellride (MCT) detector (IR detection, 700-4000 $\mathrm{cm}^{-1}$ ). Spectrums were obtained by reflected mode at a resolution of $4 \mathrm{~cm}^{-1}$ wavenumber, 128 scan and the spectrum was analyzed by OPUS 6.5 (Bruker Optic, German). The FT-IR spectra were pre-data processed by second derivative and vector normalized (S-Golay 3 polynomial at 9 point) and Extended Multiplicative Signal Correction (EMSC). The pre-data processed spectra were analyzed by Principle Component Analysis (PCA) using the Unscrambler 9.7 software package (CAMO, Norway) in order to distinguish different chemical components of the samples. The peaks were identified by IR Mentor Pro 6.5 (Bio-Rad, 1999) and an IR reference book (Mantsch and Chapman, 1996).

Table 1: Sample code of bacterial cells, non-treated and treated with $\mathrm{Zn}$ and/or $\mathrm{Cd}$

\begin{tabular}{|c|c|}
\hline Sample codes & Condition of treatment \\
\hline Native cells & EPS-enclosed cells of $P$. aeruginosa PDMZnCd2003 cultivated in nutrient broth \\
\hline EPS-free cells & EPS-removed cells of $P$. aeruginosa PDMZnCd2003 by treatment with $\alpha$-glucoamylase for $2 \mathrm{~h}$, cultivated in nutrient broth \\
\hline Native cells_Zn & EPS-enclosed cells of $P$. aeruginosa PDMZnCd2003 cultivated in nutrient broth with $\mathrm{Zn}\left(20 \mathrm{mg} \mathrm{L}^{-1}\right)$ \\
\hline Native cells_Cd & EPS-enclosed cells of $P$. aeruginosa $\mathrm{PDMZnCd} 2003$ cultivated in nutrient broth supplemented with $\mathrm{Cd}\left(20 \mathrm{mg} \mathrm{L}^{-1}\right)$ \\
\hline Native cells_ZnCd & EPS-enclosed cells of $P$. aeruginosa PDMZnCd2003 cultivated in nutrient broth supplemented with $\mathrm{Zn}$ plus $\mathrm{Cd}\left(20 \mathrm{mg} \mathrm{L}^{-1}\right.$ of Zn, Cd) \\
\hline EPS-free-cells_Zn & EPS-removed cells of $P$. aeruginosa PDMZnCd2003 cultivated in nutrient broth supplemented with $\mathrm{Zn}\left(20 \mathrm{mg} \mathrm{L}^{-1}\right)$ \\
\hline EPS-free-cells_Cd & EPS-removed cells of $P$. aeruginosa PDMZnCd2003 cultivated in nutrient broth supplemented with $\mathrm{Cd}\left(20 \mathrm{mg} \mathrm{L}^{-1}\right)$ \\
\hline & EPS-removed cells of $P$. aeruginosa PDMZnCd 2003 cultivated in nutrient broth supplemented with $\mathrm{Zn}$ plus Cd (20 \\
\hline
\end{tabular}




\section{RESULTS AND DISCUSSION}

Effects of $\mathrm{Zn}$ and Cd on growth curve: Figure $1 \mathrm{a}-\mathrm{d}$ shows the growth curves of $P$. aeruginosa PDMZnCd2003 cultivated in nutrient broth (control) and NB treated with $\mathrm{Zn}$ and/or Cd. Although, the growth curves obtained by turbidimetric method and protein assay were quite similar, the turbidimetric method was interfered by the EPS secreted by $P$. aeruginos $a$ PDMZnCd2003. Therefore, the data from the protein assay represented the bacterial growth. The growth curve indicated that bacterial cells under $\mathrm{Zn}$ and $\mathrm{Cd}$ treatment required a longer time to accelerate to the exponential growth phase and the toxicity to bacterial growth was $\mathrm{Zn}<\mathrm{Zn}$ plus $\mathrm{Cd}<\mathrm{Cd}$. Poirier et al. (2008) also reported that Pseudomonas fluorescens $\mathrm{BA} 3 \mathrm{~d} 12$ in $\mathrm{NB}$ containing $\mathrm{Zn}, \mathrm{Cu}$ and $\mathrm{Cd}$ had a longer lag phase compared to the control and $\mathrm{Zn}$ stimulated the respiration of the bacteria whereas $\mathrm{Zn}$ plus $\mathrm{Cd}$ delayed the primary metabolism of the bacteria. In addition, the color of the NB (control) after $24 \mathrm{~h}$ bacterial cultivation was changed from pale yellow to blue green. Whereas, supernatant of bacterial cultures after treated with $\mathrm{Zn}, \mathrm{Cd}$ and $\mathrm{Zn}$ plus $\mathrm{Cd}$ were orangey yellow, yellow-green and strongly yellowish green, respectively (Fig. 2a-d). P. aeruginosa PDMZnCd2003 might produce and secrete different organic molecules under $\mathrm{Zn}$ and/or $\mathrm{Cd}$ stresses. The coloring chemicals could be siderophores and the different colors of the culture media might be cause by the different concentration ratios of pyomelanin (brown), pyorubrin (red) and pyocyanin (blue) (Turick et al., 2010) or pyoverdine (yellow-green). $P$. aeruginosa $\mathrm{PDMZnCd} 2003$ was isolated from $\mathrm{Zn} / \mathrm{Cd}$ contaminated soil by NB containing $20 \mathrm{mg} \mathrm{L}^{-1}$ of $\mathrm{Zn}$ and $\mathrm{Cd}$ (Nakbanpote et al., 2010). Therefore, the concentration of $\mathrm{Zn}$ and $\mathrm{Cd}$ at $20 \mathrm{mg} \mathrm{L}^{-1}$ was used for bacterial treatment. In addition, the extractable amounts of $\mathrm{Zn}$ and $\mathrm{Cd}$ leached from the $\mathrm{Zn} / \mathrm{Cd}$ contaminated soil of Padang mine by $1 \%(\mathrm{v} / \mathrm{v}) \mathrm{HNO}_{3}$ were 8.0 and $0.8 \mathrm{mg} \mathrm{g}^{-1}$, respectively. Whereas available $\mathrm{Zn}$ and $\mathrm{Cd}$ leached from the soil with $0.005 \mathrm{M}$ Diethylenetriaminepentaacetic Acid (DTPA) were 0.15 and $0.03 \mathrm{mg}^{-1}$, respectively. Therefore, $20 \mathrm{mg} \mathrm{L}^{-1}$ of $\mathrm{Zn}$ and $\mathrm{Cd}$ used in this study was sufficient to study the effect of $\mathrm{Zn}$ and/or Cd on bacteria in the environment. The concentrations of $\mathrm{Zn}$ and/or $\mathrm{Cd}$ in Nutrient Broth (NB) at various pHs were investigated because the bacteria probably produced secondary metabolites that might increase the media $\mathrm{pH}$ and result in metal precipitation. Figure 3 shows that the $\mathrm{pHs}$ of the bacterial cultivation in NB and NB supplemented with $\mathrm{Zn}$ and/or Cd gradually increased from $7.3 \pm 0.5$ (lag phase) to
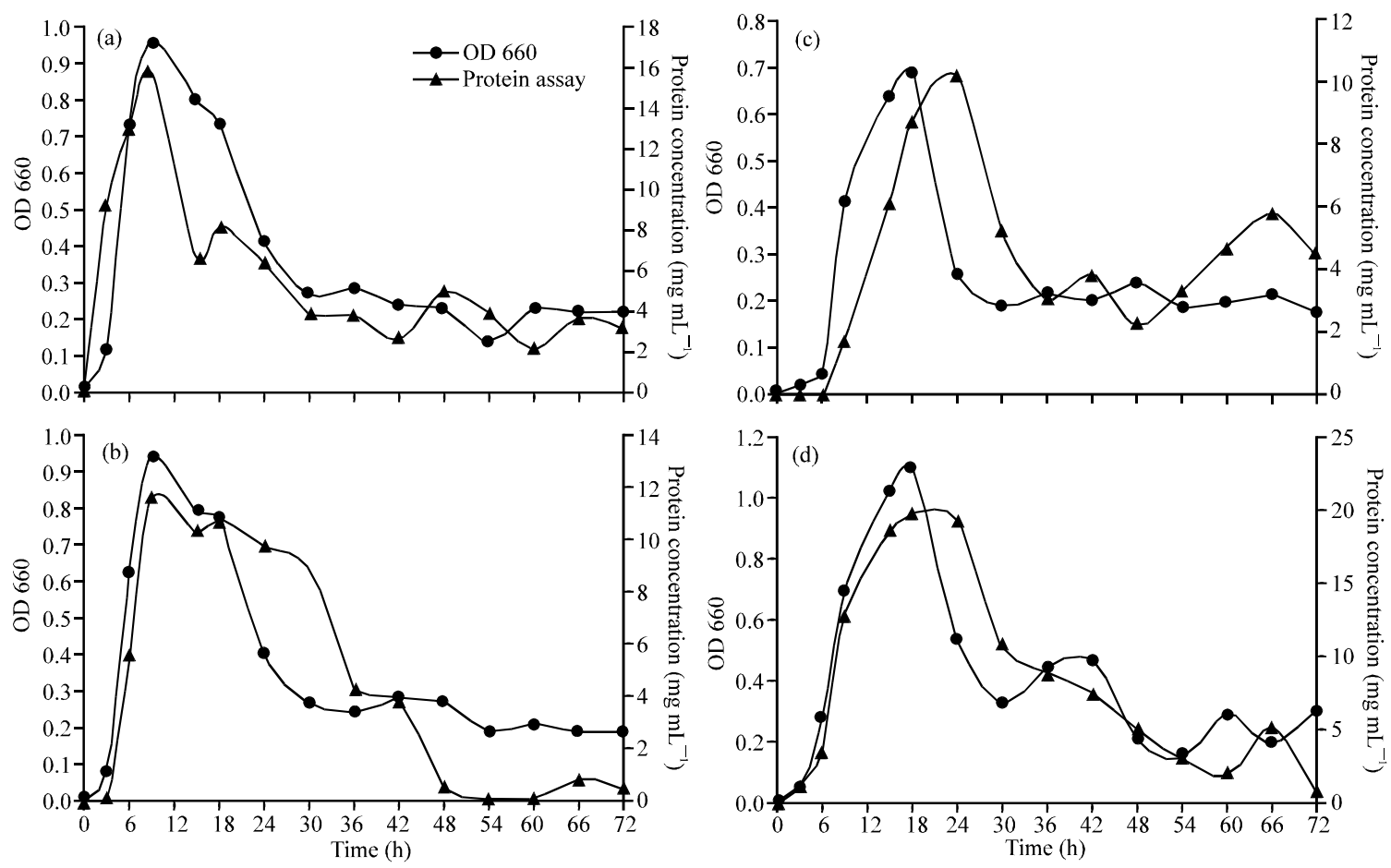

Fig. 1: Growth curves of $P$. aeruginosa PDMZnCd2003 in nutrient broth (control) and nutrient broth supplemented with $\mathrm{Zn}$ and/or $\mathrm{Cd}$, monitored by turbidimetric method and protein assay; a) Nutrient Broth (NB); b) NB with Zn; c) NB with Cd and d) NB with Zn plus Cd 
approximately 9.0 after $30 \mathrm{~h}$ (death phase). In the death phase, the stable $\mathrm{pH}$ values at $\sim 9.0$ might be caused by secondary metabolites secreted from $P$. aeruginosa PDMZnCd2003. The alkaline compounds in siderophores might be the metabolites that affected the alkaline $\mathrm{pH}$. Dao et al. (1999) reported the production and secretion of pyoverdine (yellow-green) by Pseudomonas aeruginosa under $\mathrm{Cd}$ stress. The concentration of $\mathrm{Zn}$ and $\mathrm{Cd}$ in the media decreased within $18 \mathrm{~h}$ in which the bacteria grew from lag phase to stationary phase and the system $\mathrm{pH}$ $>8.5$ (Fig. 3 a, b). Then, the concentration of $\mathrm{Zn}$ and $\mathrm{Cd}$ were stable at $13 \pm 2$ and $14 \pm 2 \mathrm{mg} \mathrm{L}^{-1}$, respectively until the death phase. In the solution with a $\mathrm{pH}$ of 8-9, the form of $\mathrm{Zn}$ dissolved was probably $\mathrm{Zn}^{2+}, \mathrm{ZnOH}^{+}, \mathrm{Zn}_{2}(\mathrm{OH})_{3}{ }^{+}$and the form of $\mathrm{Cd}$ dissolved could be $\mathrm{Cd}^{2+}, \mathrm{CdOH}^{+}$ (Stumm and Morgan, 1996). Siderophores secreted under heavy metal stress could be a chelating agent (Dao et al., 1999). In addition, amino acids in nutrient broth might chelate with $\mathrm{Zn}$ and $\mathrm{Cd}$ to form soluble complexes at alkaline $\mathrm{pHs}$. The experiments confirmed that there was no precipitation of $\mathrm{Zn}$ and $\mathrm{Cd}$ in the nutrient broth containing $20 \mathrm{mg} \mathrm{L}^{-1}$ of $\mathrm{Zn}$ and/or Cd with adjusted $\mathrm{pH}$ values of 5-9. Therefore, the decrease of $\mathrm{Zn}$ and $\mathrm{Cd}$ in NB might be

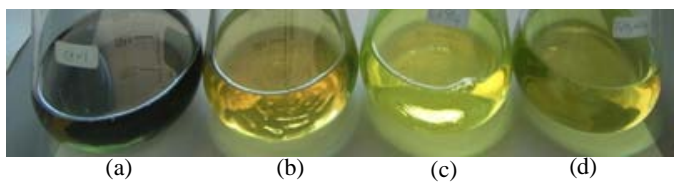

Fig. 2: Color of media after $24 \mathrm{~h}$ of bacterial cultivation in; a) Nutrient Broth (NB); b) NB with Zn; c) NB with $\mathrm{Cd}$ and d) NB with Zn plus Cd
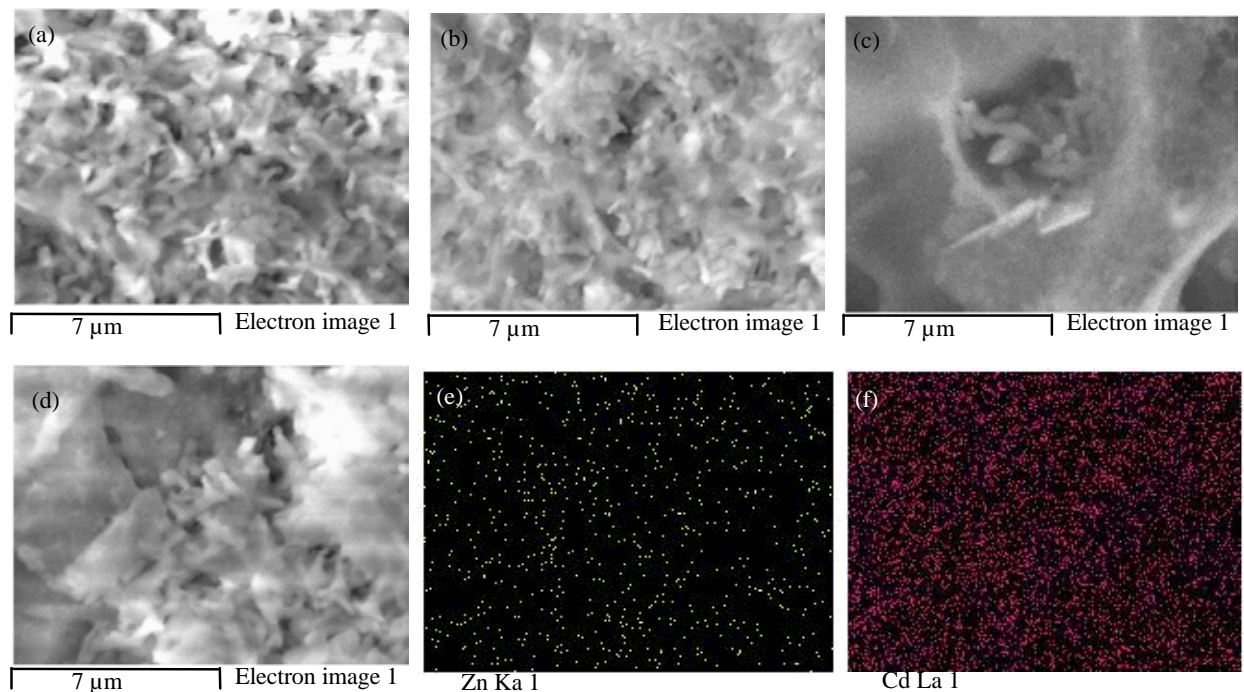

Fig. 4: SEM images of $P$. aeruginosa PDMZnCd2003 cultivated in; a) Nutrient Broth (NB); b) NB with $Z n$; c) NB with $\mathrm{Cd}$; d) NB with $\mathrm{Zn}$ and $\mathrm{Cd}$ and the EDS mapping of; e) $\mathrm{Zn}$ and f) $\mathrm{Cd}$ of the native cells_ZnCd images caused by accumulation of $\mathrm{Zn}$ and $\mathrm{Cd}$ in dissolvable forms into bacterial cells and EPS (Roane and Miller, 1994; Ueshima et al., 2008).

Bacterial cells studied by microscopy techniques: The SEM images (Fig. 4a-f) of $P$. aeruginosa PDMZnCd2003

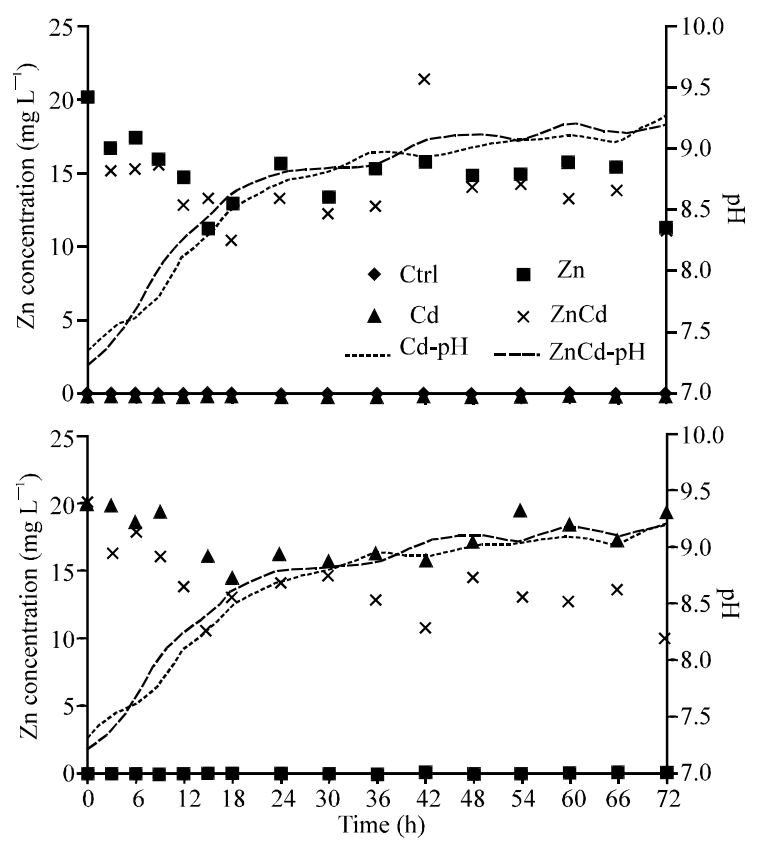

Fig. 3: Concentration of $\mathrm{Zn}$ and $\mathrm{Cd}$ during $P$. aeruginosa PDMZnCd 2003 cultivation in the Nutrient Broth (NB) (control), NB with $\mathrm{Zn}\left(20 \mathrm{mg} \mathrm{L}^{-1}\right), \mathrm{NB}$ with $\mathrm{Cd}\left(20 \mathrm{mg} \mathrm{L}^{-1}\right)$ and NB with Zn plus Cd (20 mg $\mathrm{L}^{-1}$ ) and changing $\mathrm{pH}$; a) $\mathrm{Zn}$ concentration and b) $\mathrm{Cd}$ concentration 


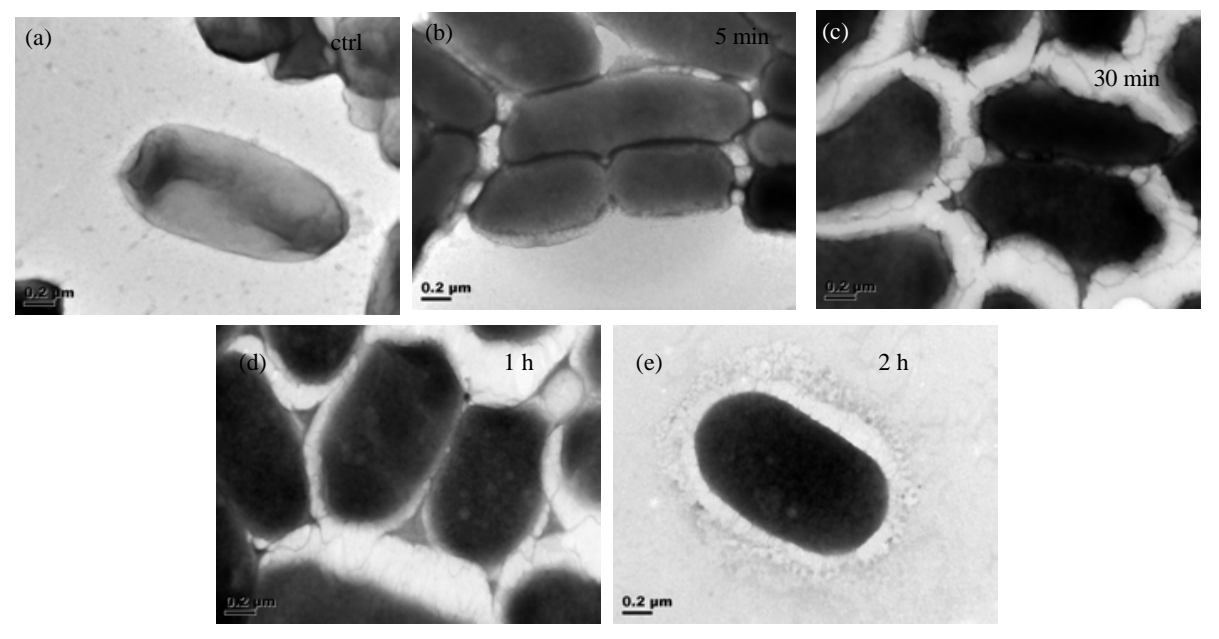

Fig. 5: TEM images of $P$. aeruginosa PDMZnCd2003 treated with $\alpha$-glucoamylase enzymes at various incubation times of; a) $0 \mathrm{~min}$; b) $5 \mathrm{~min}$; c) $30 \mathrm{~min}$; $) 1 \mathrm{~h}$ and e) $2 \mathrm{~h}(\times 40,000)$

showed a cloud of bacteria covered with numerous EPS. The appearance of a large amount of EPS under $\mathrm{Cd}$ treatment and $\mathrm{Zn}$ plus $\mathrm{Cd}$ treatment was found. The presence of large amounts of EPS indicated a mechanism to $\mathrm{Zn}$ and $\mathrm{Cd}$ toxicity. However, the evidence of $\mathrm{Zn}$ and $\mathrm{Cd}$ distribution in parts of the cells and/or EPS obtained by EDS mapping (Fig. 4e, f) was not clear because of lower electron energy and resolution. However, the important role of EPS to prevent heavy metal toxicity was published. Ueshima et al. (2008) reported Pseudomonas putida protected cells by absorbing the toxicity of $\mathrm{Cd}$ ions with EPS. Gonzalez et al. (2010) also showed the role of EPS in Cu adsorption of Pseudomonas aureofaciens as a protective barrier for cells. To study the role of EPS, $P$. aeruginosa $\mathrm{PDMZnCd} 2003$ was treated with $\alpha$-glucoamylase enzymes to remove EPS. The EPS composition of $P$ seudomonas sp. was mainly alginate-like polysaccharides. Therefore, $\alpha$-glucoamylase enzymes was applied to break $\alpha 1,4$ glucosidic bonds within alginate. However, a suitable incubation time had to be optimized to remove EPS. TEM images showed that more EPS was removed when incubation times increased. EPS continued splitting out around the cells surface and $2 \mathrm{~h}$ was the appropriated time for EPS removal (Fig. 5a-e).

Effects of $\mathrm{Zn}$ and $\mathrm{Cd}$ on biochemical molecular changes investigated by FT-IR: Since, bacteria are tiny cells, the study of biochemical alterations was carried out by FT-IR connected to a microscope. The FT-IR spectra were pre-data processed by second llderivative. The use of multivariate analysis, in particular Principle Component Analysis (PCA) has proven useful in the analysis of biospectroscopic data, providing two types of information: the visualization of the clustering of similar spectra within datasets in score plots and the identification of variables (spectral bands representing various molecular groups within the samples) in loading plots to explain the clustering observed in the scores plots. Extended Multiplicative Signal Correction (EMSC) is a transformation method used to compensate for the multiplicative, additive scatter effect in the data and to account for the physical or chemical phenomena that affect the spectra.

The difference between native cells and EPS-free cells was determined by PC1 (78\%) (Fig. 6a). The X-loading plot (Fig. 6b) indicated shifts in protein peaks, including anti-parallel, $\alpha$-turn and $\alpha$-helix in $\sim 1693-1675 \mathrm{~cm}^{-1}$, amide I at $1658 \mathrm{~cm}^{-1}$ (native cells) and 1646 (EPS-free cells), Amide I of $\alpha$-pleated sheet structure at $1602 \mathrm{~cm}^{-1}$ (native cells) and $1623 \mathrm{~cm}^{-1}$ (EPS-free cells), Amide II $1560 \mathrm{~cm}^{-1}$ (native cells) and $1535 \mathrm{~cm}^{-1}$ (EPS-free cells), sulfur peak at $1074 \mathrm{~cm}^{-1}$ (native cells) and $1081 \mathrm{~cm}^{-1}$ (EPS-free cells).

The native cells control and native cells_ $Z$ n, native cells_Cd and native cells_ $\mathrm{ZnCd}$ were analyzed in three ranges of wave numbers because the high intensity of amide peak hindered the lower intensity peak. In the lipid range $\left(3000-2800 \mathrm{~cm}^{-1}\right)$, the separation between native cells and native cells treated with $\mathrm{Zn}$ and/or $\mathrm{Cd}$ by $\mathrm{PCl}$ (71\%) (Fig. 7a), the X-loading plot (Fig. 7b) show differences in shift of $2964 \mathrm{~cm}^{-1}$ (control) and $2952 \mathrm{~cm}^{-1}$ (native cells treated with $\mathrm{Zn}$ and/or $\mathrm{Cd}$ ) and shoulder peaks at $2846 \mathrm{~cm}^{-1}$. In the protein range $\left(1800-1300 \mathrm{~cm}^{-1}\right)$, the separated native cells from the native cells treated with $\mathrm{Zn}$ and/or $\mathrm{Cd}$ by $\mathrm{PCl}(92 \%)$ (Fig. 7c), the X-loading plot (Fig. 7d) show shifts in $\alpha$ elix peaks at $1664 \mathrm{~cm}^{-1}$ control) and $1,646 \mathrm{~cm}^{-1}$ (native cells treated with $\mathrm{Zn}$ and/or $\mathrm{Cd}$ ) and shifts of the amide II peaks at $1556 \mathrm{~cm}^{-1}$ (control) and $1,537 \mathrm{~cm}^{-1}$ (native cells treated with $\mathrm{Zn}$ and/or $\mathrm{Cd}$ ). In addition, the intensity of protein 

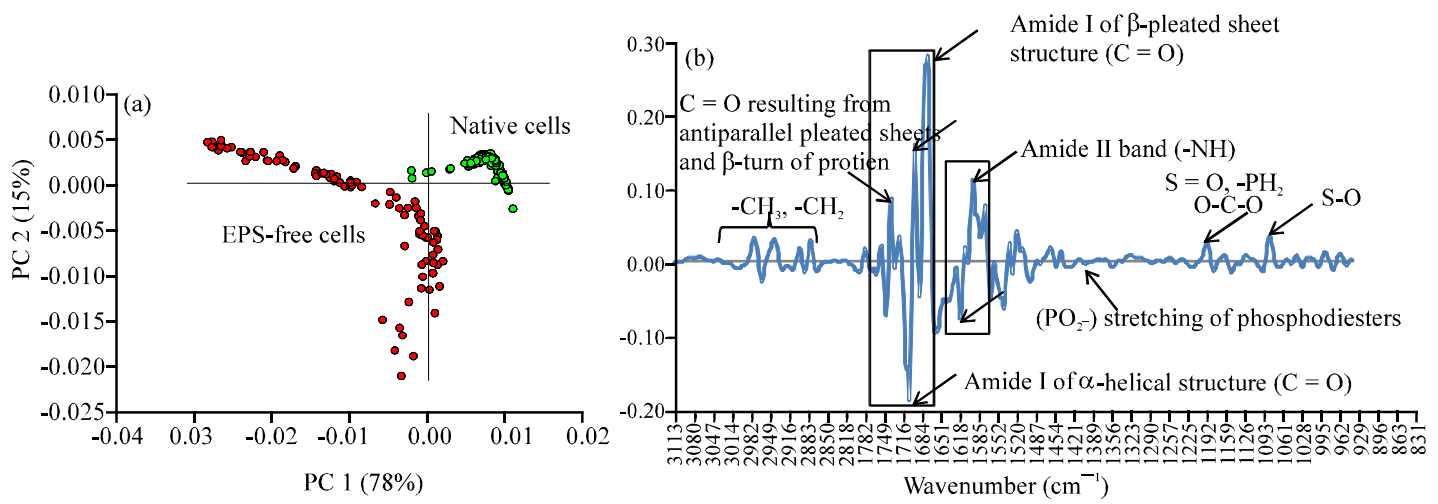

Fig. 6: Principal Component Analysis (PCA) applied to FT-IR spectra of native cells and EPS-free cells showing; a) Score plot and b) Loading plot in the range of $3200-800 \mathrm{~cm}^{-1}$
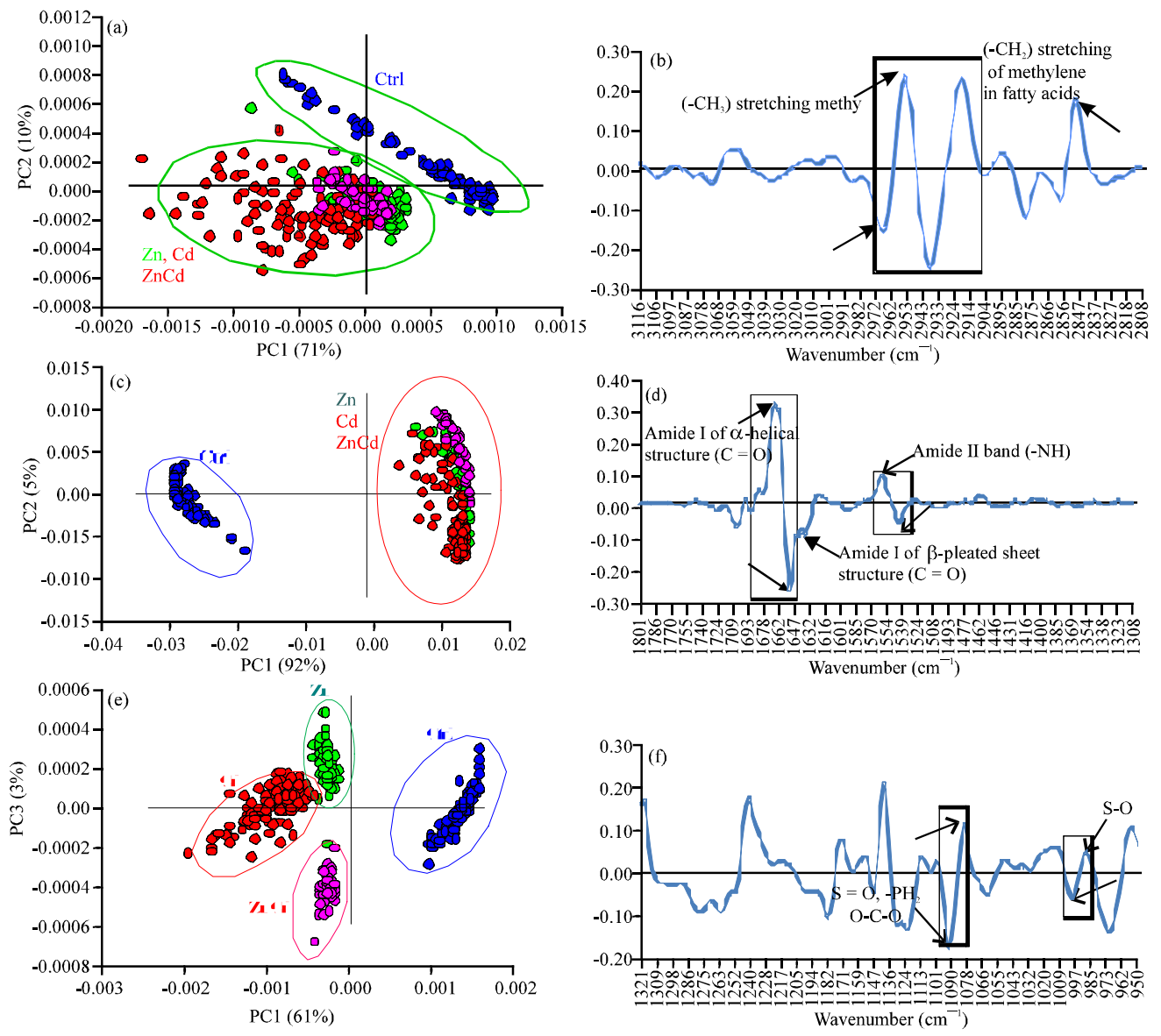

Fig. 7: Principal Component Analysis (PCA) applied to FT-IR spectra of native cells (control) and native cells_Zn, native cells_Cd and native cells_ ZnCd showing the score plot and loading plot in; a, b) Lipid range $\left(3000-2800 \mathrm{~cm}^{-1}\right)$; c, d) Protein range (1800-1300 $\left.\mathrm{cm}^{-1}\right)$ and e, f) DNA band range $\left(1300-800 \mathrm{~cm}^{-1}\right)$

peaks in native cells treated with $\mathrm{Zn}$ and/or $\mathrm{Cd}$ was higher than the control (data not shown). In the DNA band range $\left(1300-800 \mathrm{~cm}^{-1}\right)$, the separated samples divided into 4 groups by PC1 (61\%) and PC3 (3\%) (Fig. 7e) include native cells, native cells_ $\mathrm{Zn}$, native_Cd and native cells_ZnCd. The X-loading plot (Fig. 7a) found shifts of the phosphorus peaks at $1085 \mathrm{~cm}^{-1}$ (control), $1076 \mathrm{~cm}^{-1}$ (native cells treated with $\mathrm{Zn}, \mathrm{Cd}$ and $\mathrm{Zd}$ plus $\mathrm{Cd}$ ) and 
Res. J. Biol. Sci., 7 (1): 4-13, 2012
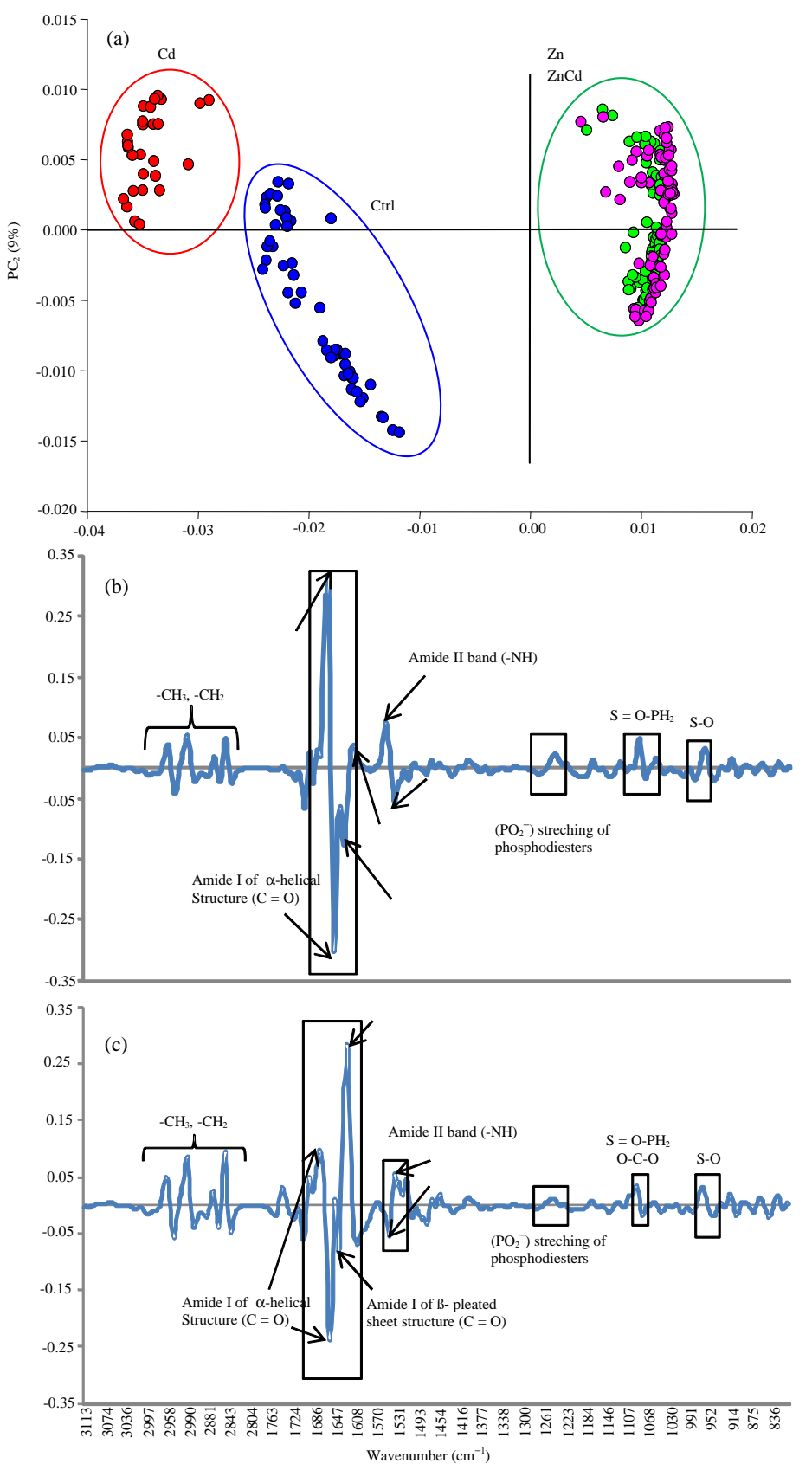

Fig. 8: Principal Component Analysis (PCA) applied to FT-IR spectra of EPS-free cells (control) and EPS-free cells_Zn, EPS-free cells_Cd and EPS-free cells_ZnCd showing the score plot; a) X-loading plots of PC1; b) PC2 and c) in the range of $3200-800 \mathrm{~cm}^{-1}$

sulfur peaks at 1081, $993 \mathrm{~cm}^{-1}$ (control) and 1076, $981 \mathrm{~cm}^{-1}$ (native cells treated with $\mathrm{Zn}, \mathrm{Cd}$ and $\mathrm{Zd}$ plus $\mathrm{Cd}$ ). The EPS-free cells (control) and EPS-free cells_Zn, EPS-free cells_Cd and EPS-free cells_ZnCd were separated into three groups of; EPS-free cells (control), EPS-free cells_Cd and EPS-free cells_Zn and EPS-free cells_ZnCd by PC1 $(88 \%)$ and PC2 (9\%) (Fig. 8a). Control and EPS-free
cells_Cd were separated from EPS-free cells_Zn and EPS-free cells ZnCd by the shifts of $\alpha$-helix at $1 \overline{6} 60 \mathrm{~cm}^{-1}$ (EPS-free cells and EPS-free cells_Cd) and $1648 \mathrm{~cm}^{-1}$ (EPS-free cells_Zn and EPS-free cells_ZnCd) and shifts of amide II at $1552 \mathrm{~cm}^{-1}$ (EPS-free cells and EPS-free cells_Cd) and $1537 \mathrm{~cm}^{-1}$ (EPS-free cells_Zn and EPS-free cells_ZnCd) (Fig. 8b). EPS-free cells (control) were 
separated from EPS-free cells treated with Cd by the PC2 axis. The X-loading (PC2) (Fig. 8c) and average spectra indicated the difference between EPS-free cells and EPSfree cells_Cd was at the $\alpha$-helix $\left(1656 \mathrm{~cm}^{-1}\right)$ and shifts of the $\alpha$-plated sheet peak at $1621 \mathrm{~cm}^{-1}$ in EPS-free cells (control) and $1639 \mathrm{~cm}^{-1}$ in EPS-free cells_Cd. For FT-IR analysis, the shifts of the $\alpha$-helix and amide II peaks might be caused by the functional groups of $\mathrm{C}=\mathrm{O}$ and $-\mathrm{NH}$ binding to $\mathrm{Zn}$ and $\mathrm{Cd}$ ions. In addition, there were the shift of sulfur groups and $\mathrm{C}$-O bonds in both native cells and EPS-free cells after $\mathrm{Zn}$ and/or Cd treatments. The lone pairs of electrons in the carboxyl groups and amine groups indicated coordinate covalent bonds with heavy metal ions. In addition, chelating agents and various metabolites secreted by the bacterium could bind to heavy metal ions. There have been many studies about the functional groups that bacteria use to bind with heavy metal ions. Choudhary and Sar (2009) showed the relationship between carboxyl groups and phosphoryl groups on heavy metal ions binding in Pseudomonas sp. Chen et al. (2007) showed that Pseudomonas putida CZ1 bound $\mathrm{Cu}$ and $\mathrm{Zn}$ ions by carboxyl groups mainly. Kazy et al. (2009) also reported Pseudomonas sp., binding with $U$ and Th by phosphoryl, carboxyl and amide groups. These separations resulting from PCA (Fig. 8a) indicated that $P$. aeruginosa $\mathrm{PDMZnCd} 2003$ responds to $\mathrm{Zn}$ unlike $\mathrm{Cd}$ and the cells might have different mechanisms for $\mathrm{Zn}$ and $\mathrm{Cd}$ effects. The possible $\mathrm{Cd}$ tolerance mechanism of $P$. aeruginosa $\mathrm{PDMZnCd} 2003$ was the production and secretion of proteins and/or protein compounds due to the highest peak of protein in the EPS-free cells treated with $\mathrm{Cd}$.

The secretions could prevent $\mathrm{Cd}$ ions binding to or entering the cells since $\mathrm{Cd}$ is more toxic than $\mathrm{Zn}$ which is an essential element for bacterial growth. The role of EPS in preventing cells from being damaged by heavy metal ions has been reported to occur by EPS enhancing heavy metal uptake and then retarding them to the cell wall (Fang et al., 2011; Ha et al., 2010; Ghannoum and O'Toole, 2004; Ueshima et al., 2008; Gonzalez et al., 2010). In addition, EPS-free cells had higher intensities of phosphoryl groups and nucleic acid than EPS-free cells treated with $C d$ because DNA might be damaged by toxic Cd (Zhou et al., 2008).

Some enzymes and/or Metallothionines (MTs) might be responsible for binding with heavy metals. There have been many studies about proteins that bacteria expressed under heavy metal stress. Pereira et al. (2006) found that $\mathrm{Cd}$ could induce alterations in metabolite proteins in Rhizobium sp. Sample FT-IR spectra from the DNA band region showed the control samples had higher nucleic acid, phospholipids or phosphoryl groups than the $\mathrm{Zn}$, $\mathrm{Cd}$ and $\mathrm{ZnCd}$ treatments. Heavy metals can damage nucleic acid and are toxic to cells. Zhou et al. (2008) showed that an increase in $\mathrm{As}^{3+}, \mathrm{Cd}^{2+}, \mathrm{Cr}^{3+}, \mathrm{Cu}^{2+}, \mathrm{Hg}^{2+}$, $\mathrm{Pb}^{2+}$ and $\mathrm{Zn}^{2+}$ ion concentrations lead to damaged DNA of Effective Microorganisms (EMs) in wastewater.

\section{CONCLUSION}

Although, Pseudomonas aeruginosa PDMZnCd2003 was isolated from $\mathrm{Zn} / \mathrm{Cd}$ contaminated soil near the rhizosphere of a $\mathrm{Zn} / \mathrm{Cd}$ hyperaccumulative plant, $\mathrm{Zn}$ and $\mathrm{Cd}$ delayed the bacterial growth. However, the bacterium had $\mathrm{Zn} / \mathrm{Cd}$ tolerance mechanisms. FT-IR indicated that the biochemical structures involved in $\mathrm{Zn}$ and $\mathrm{Cd}$ accumulation were carbonyl, amine groups, protein containing thiol (-SH) groups and C-O bonds. EPS and yellow-green chemicals secreted under $\mathrm{Zn} / \mathrm{Cd}$ stress might help the bacterium decrease the metals' toxicity.

Moreover, P. aeruginosa PDMZnCd2003 showed some specific mechanisms to tolerate $\mathrm{Cd}$ which were different from the mechanism responding to $\mathrm{Zn}$ and $\mathrm{Zn}$ plus $\mathrm{Cd}$. In addition, this research indicated that $P$. aeruginosa PDMZnCd2003 secreted specific siderophores as various shades of yellow-green chemicals to reduce the toxicity of $\mathrm{Zn}$ and/or $\mathrm{Cd}$. Therefore, chemical analysis and properties of the siderophores in $\mathrm{Zn} / \mathrm{Cd}$ tolerance mechanisms should be study further.

\section{ACKNOWLEDGEMENTS}

The researchers would like to thanks Asst. Prof. Dr. Aphidech Sangdee, Department of Biology, Faculty of Science, Mahasarakham University for help and support on bacterial identifications and thanks Dr. Jolyon Dodgson for English proofreading. Meesungnoen O. gratefully thanks the National Synchrotron Research centre (GS-52-M07) for a graduate study scholarship and thanks Mahasarakham University for financial support to give an oral presentation in India.

\section{REFERENCES}

Baker, A.J.M., K. Ewart, G.A.F. Hendry, P.C. Thorpe and P.L. Walker, 1990. The evolutionary basis of cadmium tolerance in higher plants. Proceedings of the 4th International Conference on Environmental Contamination, October 1-4, 1990, Barcelona, Spain, pp: 23-29.

Blaylock, M.J. and J.W. Huang, 2000. Phytoextraction of Metals. In: Phytoremediation of Toxic Metals: Using Plants to Clean up the Environment, Raskin, I. and B.D. Ensley (Eds.). John Wiley and Sons, New York, pp: 53-70. 
Bradford, M.M., 1976. A rapid and sensitive method for the quantitation of microgram quantities of protein utilizing the principle of protein-dye binding. Anal. Biochem., 72: 248-254.

Chen, X.C., J.Y. Shi, Y.X. Chen, X.H. Xu, L.T. Chen, H. Wang and T.D. Hu, 2007. Determination of copper binding in Pseudomonas putida CZ1 by chemical modifications and X-ray absorption spectroscopy. Applied Microbiol. Biotechnol., 74: 881-889.

Choudhary, S. and P. Sar, 2009. Characterization of a metal resistant Pseudomonas sp. isolated from uranium mine for its potential in heavy metal $\left(\mathrm{Ni}^{2+}, \mathrm{Co}^{2+}, \mathrm{Cu}^{2+}\right.$ and $\mathrm{Cd}^{2+}$ ) sequestration. Bioresour. Technol., 100: 2482-2492.

Dao, K.H.T., K.E. Hamer, C.L. Clark and L.G. Harshman, 1999. Pyoverdine production by Pseudomonas aeruginosa exposed to metals or an oxidative stress agent. Ecol. Appl., 9: 441-448.

Fang, L., X. Wei, P. Cai, Q. Huang, H. Chen, W. Liang and X. Rong, 2011. Role of extracellular polymeric substances in $\mathrm{Cu}(\mathrm{II})$ adsorption on Bacillus subtilis and Pseudomonas putida. Bioresour. Technol., 102: 1137-1141.

Ghannoum, M.A. and G.A. O'Toole, 2004. Microbial Biofilms. ASM Press, Washington, DC., USA., ISBN13: 9781555812942 , Pages: 426.

Gonzalez, A.G., L.S. Shirokova, O.S. Pokrovsky, E.E. Emnova and R.E. Martinez et al., 2010. Adsorption of copper on Pseudomonas aureofaciens: Protective role of surface exopolysaccharides. J. Colloid Interface Sci., 350: 305-314.

Ha, J., A. Glabert, A.M. Spormann and G.E. Brown Jr., 2010. Role of extracellular polymeric substances in metal ion complexation on Shewanella oneidensis: Batch uptake, thermodynamic modeling, ATR-FTIR and EXAFS study. Geochim. Cosmochim. Acta, 74: 1-15.

Jing, Y.D., Z.L. He and X.E. Yang, 2007. Role of soil rhizobacteria in phytoremediation of heavy metal contaminated soils. J. Zhejiang Univ. Sci. B, 8: 192-207.

Kabata-Pendias, A. and H. Pendias, 1992. Trace Element in Soils and Plant. 2ndEdn., CRC Press, Florida, USA.

Kazy, S.K., S.F. D'Souza and P. Sar, 2009. Uranium and thorium sequestration by a Pseudomonas sp.: Mechanism and chemical characterization. J. Hazard. Mater., 163: 65-72.

Mantsch, H.H. and D. Chapman, 1996. Infrared Spectroscopy of Biomolecules. Wiley-Liss, Inc., New York.

Mukerji, K., C. Manoharachary and J. Singh, 2006. Microbial Activity in the Rhizosphere. Springer, Germany.
Nakbanpote, W., N. Panitlertumpai, K. Sukadeetad, O. Meesungneon, and W. Noisa-Nguan, 2010. Advances in Phytoremediation Research: A Case Study of Gynura pseudochina (L.). In: Advanced Knowledge Application in Practice, Furstner, I. (Eds.). SCIYO, Croatia, pp: 353-378.

Panitlertumpai, N., B. Mongkonsin, W. Nakbanpote and P. Jitto, 2008. Zinc hyperaccumulation by Gynura pseudochina (L.) DC. Zinc processing. Stamford Plaza Hotel, Brisbane, Australia.

Pereira, S.L., A.L. Lima and E.M. Figueira, 2006. Screening possible mechanisms mediating cadmium resistance in rhizobium leguminosarum bv. viciae isolated from contaminated portuguese soils. Microbial. Ecol., 52: $176-186$.

Phaenark, C., P. Pokethitiyook, M. Kruatrachue and C. Ngernsansaruay, 2009. Cd and $\mathrm{Zn}$ accumulation in plants from the Padaeng zinc mine area. Int. J. Phytorem., 11: 479-495.

Poirier, I., N. Jean, J.C. Guary and M. Bertrand, 2008. Responses of the marine bacterium Pseudomonas fluorescens to an excess of heavy metals: Physiological and biochemical aspects. Sci. Total Environ., 406: 76-87.

Prasad, M.N.V., H. Freitas, S. Fraenzle, S. Wuenschmann and B. Markert, 2010. Knowledge explosion in phytotechnologies for environmental solutions. Environ. Pollut., 158: 18-23.

Rajkumar, M., N. Ae, M.N.V. Prasad and H. Freitas, 2009. Potential of siderophore-producing bacteria for improving heavy metal phytoextraction. Trends Biotechnol., 28: 142-149.

Rascio, N. and F. Navari-Izzo, 2011. Heavy metal hyperaccumulating plants: How and why do they do it? And what makes them so interesting? Plant Sci., 180: $169-181$.

Roane, T.M. and P. Miller, 1994. Microbial Remediation of Metals. In: Bioremediation Principles and Applications Great Britain, Craford, L., Ronolad and L. Cfawford Don (Eds.). Cambridge University Press, UK., pp: 312-340.

Simmons, R.W., P. Pongsakul, D. Saiyasitpanich and S. Klinphoklap, 2005. Elevated levels of cadmium and zinc in paddy soils and elevated levels of cadmium in rice grain downstream of a zinc mineralized area in Thailand: Implications for public health. Environ. Geochem. Health, 27: 501-511.

Simmons, R.W., A.D. Noble, P. Pongsakul, O. Sukreeyapongse and N. Chinabut, 2009. Cadmiumhazard mapping using a general linear regression model (Irr-Cad) for rapid risk assessment. Environ. Geochem. Health, 31: 71-79. 
Stumm, W. and J.J. Morgan, 1996. Aquatic Chemistry: Chemical Equilibria and Rates in Natural Waters. 3rd Edn., Wiley Interscience, New York, USA.

Swaddiwudhipong, W., P. Limpatanachote, P. Mahasakpan, S. Krintratun and C. Padungtod, 2007. Cadmium-exposed population in Mae Sot District, Tak Province: 1 . Prevalence of high urinary cadmium levels in the adults. J. Med. Assoc. Thai., 90: 143-148.

Swaddiwudhipong, W., P. Mahasakpan, T. Funkhiew and P. Limparanachote, 2010. Changes in cadmium exposure among persons living in cadmiumcontaminated areas in northwestern Thailand: A five-year follow-up. J. Med. Assoc. Thai., 93: 1217-1222.
Teeyakasem, W., M. Nishijo, R. Honda, S. Satarug, W. Swaddiwudhipong and W. Ruangyuttikarn, 2007. Monitoring of cadmium toxicity in a Thai population with high-level environmental exposure. Toxicol. Lett., 169: 185-195.

Ueshima, M., B.R. Ginn, E.A. Haack, J.E.S. Szymanowski and J.B. Fein, 2008. Cd adsorption onto Pseudomonas putida in the presence and absence of extracellular polymeric substances. Geochim. Cosmochim. Acta, 72: 5885-5895.

Zhou, S., C. Wei, C. Liao and H. Wu, 2008. Damage to DNA of effective microorganisms by heavy metals: Impact on wastewater treatment. J. Environ. Sci., 20: 1514-1518.

Zhuang, X., J. Chen, H. Shim and Z. Bai, 2007. New advances in plant growth-promoting rhizobacteria for bioremediation. Environ. Int., 33: 406-413. 